\title{
MORAL EDUCATION FOR CHILDREN WITH SPECIAL NEEDS THROUGH THE HABITUATION OF RELIGIOUS ACTIVITIES
}

\author{
Muhammad Farisi Abror, Bayu Widiyanto, Moh. Fadli \\ Postgraduate of Universitas Negeri Surabaya \\ E-mail: mfarisia@gmail.com
}

\begin{abstract}
Children with special needs require assistance to protect and optimize growth. All the elements of child development in children with special needs to be optimized, including the development of norms and religion so that it can develop well. The development optimization can do practice in the family, schools, and communities by carrying out religious activities habituation.
\end{abstract}

Keywords: developmental norms, habituation, religious.

\section{PRELIMINARY}

The presence of companions for children with special needs has meaning for the process of protection and growth. Therefore, knowledge and capacity building of the assistant, it's parents, family, and community, in dealing with children with special needs from an early age will have a significant impact in maintaining, nurturing, educating, and mixing the talents or potentials of each child with special needs. The readiness and preparedness of parents and families who have children with special needs is the key to successful treatment, plus the support of the community and the government in providing a friendly environment and facilities for children with special needs (Kementerian Pemberdayaan Perempuan: 2013)

One of the most important phases in the episode of human life is the developmental phase of a person. Understanding development means the occurrence of a process of change both physiological and psychological toward a more perfect. The development is always fixed, so it will not be played back or restored to its original position. That is why the developmental phase is the most critical episode in the life span of a child, because of the developmental impact, regardless of the contents that are constantly processing for life. In other words, meaningful progress to a systemic change is not random. Changes are permanent or permanent, not temporary or momentary. It happens continuously instead of fluctuations within a certain period of one's life. Not just in one year or one generation but along the line. Likewise happens to all people, not specific people and is closely related with age and life experience.

Every human being must have gone through the stages of moral development, whether special or not. Moral development is the process of awareness that in life there are rules that bring something to do and a ban to do. Children begin to recognize the moral concepts (knowing right 
wrong or good and bad first of a family environment. At first, the child may not understand the concept of this moral, but gradually the child will understand. Business instill moral concepts at an early age (preschool) is supposed, because information received by the child about right or wrong or good-bad will be a guide to his behavior in the future. Moral development in primary school age, children can follow the linkage or demands of the parents or social environment At the end of this age, children are able to understand the reasons underlying an ordinance in addition, children are able to associate any form of behavior with the concept of right and wrong or good and bad example, he looked at or considered that the actions of rogue lie, and no disrespect to parents a false or bad. While doing an honest, fair, and respect attitude to parents and teachers is a right / good.

Addressing children with special needs, counselors need knowledge of the children, nurturing skills and serving them. Children with special needs need to get encouragement, guidance, and practice directly in stages. The potential of children with special needs will grow along with the success of the companion role in understanding and foster the potential of these children (Kementerian Pemberdayaan Perempuan:: 2013). The provision of training or habituation religious activities is one of the main ways to morally educate children with special needs. However the crew must obey the norms and rules of religion. Therefore it is necessary to study about moral education for children with special needs.

\section{Habituation religious activities for children with special needs}

The children with special needs are children who have limited or exceptionalism, whether physical, mental, intellectual, social, and emotional, having significant influence in the process of growth or development, compared with other children his own age. In educating the moral of crew there is similarity by educating the moral of normal children. Character education is a powerful way to educate children morally. One method of educating the moral is by habituation. Imam Al-Ghazali explained that the method is a method to train children the most important and foremost, if children are trained to do goodness will grow up to be good and happy afterlife (Abdurrahman in Ansor, 2013: 156). An ongoing activities will become habit, with habituation something will be easy (AlMaghribi in Anshor, 2013: 159).

Activeities to religious habituation for children with special needs would have to be adapted to the moral development as well as special children have integrity. In the preschool years, children already have the basis of attitudes toward social groups (parents, siblings and peers). Through the experience of interacting with (parents, siblings and peers) children learn about an activity or behavior to understand what is good or bad may be accepted approved should not be denied is not approved by the understanding then at this time the child must get used to the trained he should 
behave (like washing his hands before eating, brushing his teeth before bed and reading basmalah before eating). While the teenage years appears the urge to do something - acts that can be considered good by others. Adolescent behavior speak not only to meet the physical satisfaction, but psychology satisfaction with their acceptance and positive assessment about his actions (Yusuf: 2011).

Several phases of moral development show that every child has their own development. The moral development of children must continue to develop in accordance with the phases in order to continue to be a better human being. therefore it is necessary to moral education so that children can have a good moral. this is where the need for habituation. Habits that need to be given to the crew is the habituation of religious activities. Religious customs need to be given to the crew more intensively in order to be more accessible. Based on its area of religious practice are distinguished three, namely 1) religious practice in the family; 2) religious practice in the family; 3) religious practice in the community.

Conceptual study of each habituation religious as follows:

\section{Religious habituation in the Family}

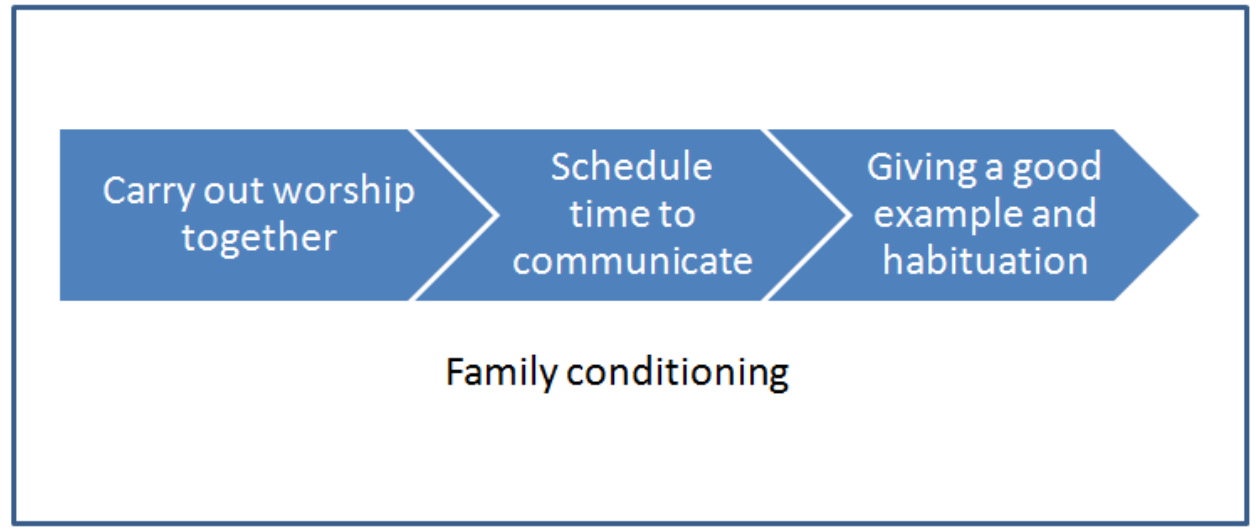

Figure 1. Religious Habituation Systems in Family

Before entering school age, the children with special needs has obtained education in the family. The children with special needs also continues to get educated in the family even though there is a portion reduced by formal education. However, family education still has a bearing effect on The children with special needs.

Religious habituation program in the family can begin with the family conditioning to perform religious habituation behalf. Conditioning can be done by uniting the idea that the habituation is good to family members who have special needs. Conditioning of the family it is important that in the implementation of moral education for the crew to be carried out can run smoothly without any family members who disrupt the moral education. 
Once conditioning has been done, then do religious habituation its behalf, namely through the implementation of joint worship, determining the time schedule to communicate together and rule provides a good example and habituation well behaved. do worship with family members every day or every week. It can stimulate the development of norms and religion of students that humans have an obligation to worship god. Scheduling communicating together provides an opportunity for parents to advise, the children with special needs on the rules of family and community. It also help the children with special needs practice how to communicate and provide insight to the crew of the good and bad behavior. Giving to $t$ eladanan and crew behaved habituation to do with give examples or exemplary daily activities such as eating, bathing and cleaning the house were aimed so crews can imitate such good activities. In addition also can train crew behaved in accordance with the norms prevailing in the family.

\section{Religious habituation in Schools}

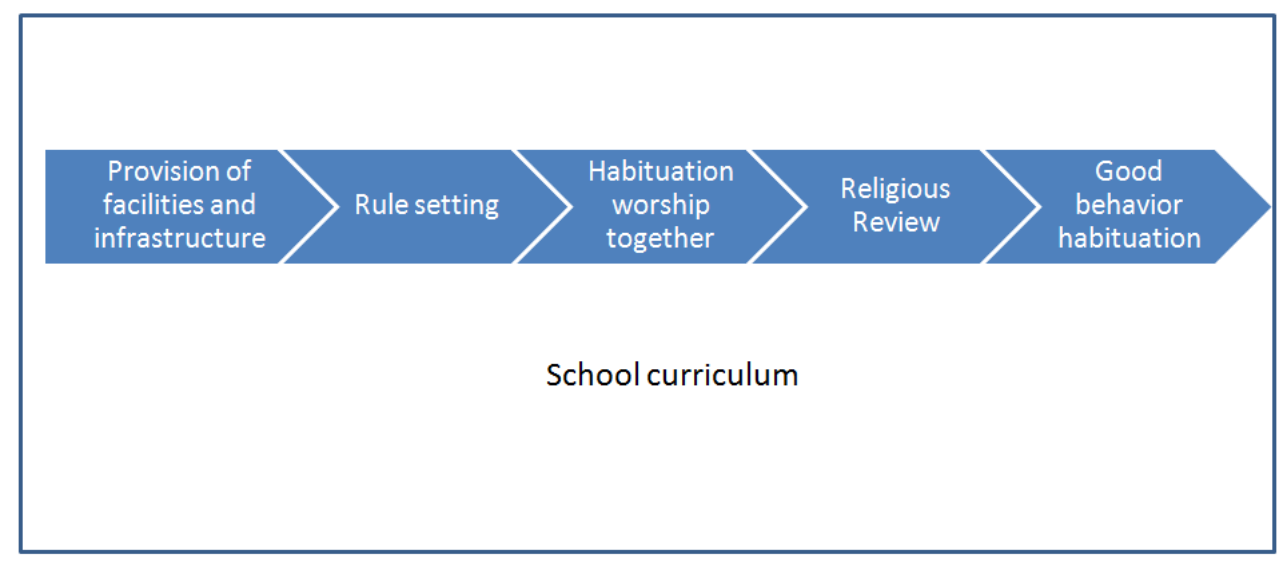

Figure 2 Religious habituation in the school system

The children with special needs norm development continues to evolve with increasing age. When the crew has entered the age of the school, the crew will be exposed to a new environment that the school environment, friends, teachers and education classes in schools. The new environment is different from the previous environment that is family environment. The children with special needs in this school environment to learn new norms and rules, as well as new educational style education.

Schools will implement moral education for the crew must have a school curriculum to support the implementation of education, ranging from a curriculum guide to the facilities and infrastructure. Provision of facilities and infrastructure such as clean water, worship equipment and worship space must be available. The availability of these facilities and 
infrastructure does not have to belong to the school, but also can be borrow to the community. It is that process of habituation religious activities can be performed well. after the available facilities and infrastructure, schools need to establish regulations regarding the implementation of the activities of religious habituation. The arrangement of the rules so that all citizens of the school can know and adhere to the rule. Habituation of religious activities can be done through the habit of carrying out the worship together. Thus, the children with special needs can know and practice to carry out its obligations as a religious community. Schools also need to implement habituation studied religion through the study of theology so that the crew know the do's and don'ts in the science of religion. The religious studies can be carried out in cooperation with religious leaders around the school. In addition to theoretical studies, the children with special needs also need to practice the religion of knowledge, so it needs to behave bai habituation undertaken in accordance with the guidance of religion. Habituation well behaved can be done by habituation cleaning up the environment, care for the school garden and behave example where someone else. So that the religious refraction can earn greater benefit, schools need to collaborate with students' families and communities so that development can be observed the children with special needs norm and continually educated.

\section{Religious habituation in the Community}

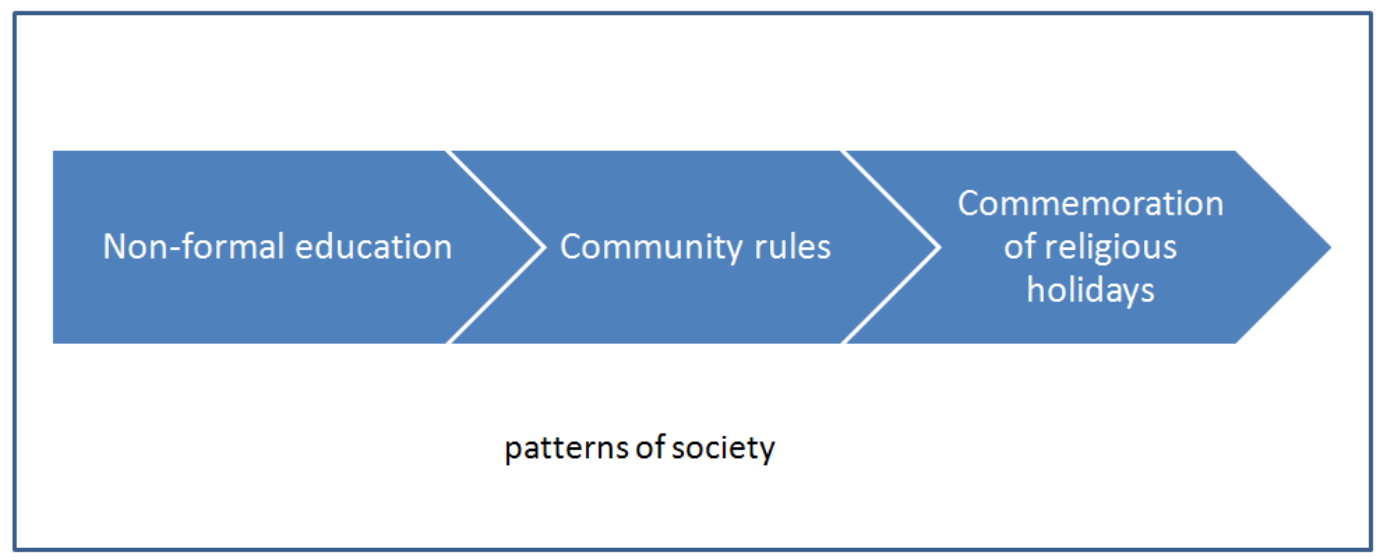

Figure 3 System religious habituation in society

The children with special need's most extensive social environment is the community environment. Good or bad humans are also influenced by the environment, including the community environment. Therefore, people should have a positive impact on the development of the crew, including the impact on moral development. 
Habituation of religious activities can be more easily implemented if the community has been patterned to educate its members. If society is not yet patterned, it must begin to form a habitual pattern in the society so that the education of community members can flow following the pattern that has been blessed. Citizens also need to organize the activity of non-formal education such as youth organizations, educational Al-Quran, routine recitation and public education. The training can train or familiarize the crew with knowledge, even if they are not in school. Besides the non-formal educational activities can also broaden knowledge about the norms and religious the children with special needs. To form a good community pattern, it is necessary to set up a regulation that must be obeyed by all levels of society. People who obey per rules will give exemplary to the crew and to provide knowledge and familiarity with the norms of appropriate behavior. Celebrating religious holidays is also society pattern to provide religious customs for the crew. By commemorating the religious holidays such as the new year of hijriyah, the money of the birth year of the prophet and the celebration of religious festivities, the crew can mingle with the people and get used to the religious celebration.

\section{CONCLUSION}

Moral education for the crew through the habituation of religious activities, based on its environment is divided into three namely, 1) religious practice in the family environment; 2) religious practice in school environments; 3) religious customs in the community. The most important component in implementing $\mathrm{ABK}$ standard education through the habituation of religious activities in these three environments is family conditioning, school curriculum and community patterns..

\section{BIBLIOGRAPHY}

Ansor, M. Mujib. 2013. Pendidikan Karakter Berbasis Sunnah Nabi SAW (Kunci Sukses Membangun Karakter Anak Bangsa). Malang: pustaka al-Umm.

Kementerian Pemberdayaan Perempuan., 2013. Panduan Penanganan Anak Berkebutuhan Khusus Bagi Pendamping (Orang Tua, Keluarga, dan Masyarakat). http://www.kemenpppa.go.id/lib/uploads/list/b3401-panduan-penanganan-abk-bagipendamping-_orang-tua-keluarga-dan-masyarakat.pdf

Yusuf,Samsu. 2011. Psikologi perkembangan anak dan remaja. Bandung: Rosda karya. 